\title{
110 形状記憶合金を用いた可逆的形状変化スマート構造の解析
}

\section{Analysis of Reversible Shape Changing Smart Structure using Shape Memory Alloys}

\author{
○正 永井 英幹 (産総研) \\ 大石竜太郎（産総研） \\ 許 亜(物材機構) \\ 正吉田均 (産総研) \\ 阿見 則男（千代田メインテナンス）
}

Hideki NAGAl, National Institute of Advanced Industrial Science and Technology (AIST), 1-1-1, Umezono, Tsukuba, Ibaraki

Ryutaro OISHI, AIST

XU Ya, National Institute of Materials Science

Hitoshi YOSHIDA, AIST

Norio AMI, Chiyoda Maintenance Co., Ltd

\begin{abstract}
This paper describes a study of smart structure composed of Ti-Ni shape memory alloys (SMA) and elastic materials. SMA is one of the effective materials which posses actuator function for start structure. However, in the conventional application of SMA, its shape change is non-reversible. Under certain conditions, SMA can show two-way shape memory effect (SME). But conventional two-way SMA is not used for smart structure because stability of the effect and strength of generated force is not sufficient. Composing SMA with elastic materials, the structures can response reversibly depending on temperature. In this paper, ring-shape type, which contains CFRP as the elastic materials, is investigated. Analytical models of reversible shape change and generated forces are led based on beam theory. The validity of the models is shown by comparison with experimental results.
\end{abstract}

Key Words : Smart Structure, Shape Memory Alloys, CFRP, Reversible Shape Change

\section{1. 緒言}

知的材料・構造においてアクチュエータ機能を発現する 材料として、形状記憶合金(SMA)は有力な地位を占める材 料である。逆変態時に生じる回復力を利用して、振動や損 傷の制御に利用されている 1)。しかし、通常は形状記憶効 果が利用可能なのは一方向のみであるため、応用対象に限 りがある。筆者らは、SMAを金属、高分子材料などの弾性 体と複合化し、形状記憶効果に二方向性（可逆性）を有す る複合材料を開発してきた。主として、その複合体の変形 ストロークが大きくとれるコイル型やリング型について取 り組んできているが、本稿ではリング型の場合を対象とし、 本材料の重要な性能となる形状変化と発生荷重について、 解析値を平易なモデルで導き、実験により検証した結果を

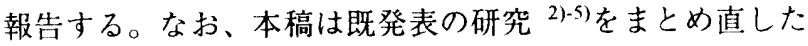
ものである。

\section{2. 可逆的形状変化棈合体}

\section{1 原理}

SMAのみでも、特定の条件のもと、特定の処理を加えれ ば、二方向性を得ることは可能ではある。しかし、処理が 簡単ではないことに加え、得られる効果の持続性・一定性、 双力向で発生する形状変化や荷重が容易に設計できるかの 点で、実用化には難点がある。また、バイアスバネを用い て構造として二方向性を実現する手段が多用されるが、ス マート構造においてアクチュエータとして利用する場合、 そのような外部部材が利用可能とは限らず、なるだけ少な いアクチュエー夕自身で複数の機能を発現する方が望まし い。ここで示す構造体は、それ自身で二方向性を有するも のである。

相変態前後で剛性が大きく変化する SMA ワイヤ(TiNi 合 金を用いた)と、大きな変形に耐える高勒性な弾性体を複合 化するが、このとき SMAの記憶形状と弾性体の形状を異 なる形状（リング型の場合、異なる曲率半径）で作製し、 複合化する。これにより、可逆的形状変化を実現している。

\section{2 形状変化と発生荷重のモアル化}

Fig.1 は本スマート構造の動作および複合化の前後にお ける形状を表した模式図である。ここでは、高温時に複合 体が閉じて、低温時に開く動作をする場合を取り上げてい る。弧 OA,OAが SMA ワイヤのみの場合で、SMAの変態 温度以下の低温時、逆変態温度以上の高温時における形状 を示し、 $R_{a l} R_{a h}$ がそれぞれ低温時、高温時の場合における 曲率半径を表す。弧 $\mathrm{OB}$ は母材（弾性体）のみの場合、弧 OC,OC'は母材と SMA を複合化した場合のそれぞれ低温時、 高温時を表し、曲率半径はそれぞれ $R_{m}, R_{c l}, R_{c h}$ である。ま ず低温時において、図に示すように、母材と SMA に曲げ モーメント (それぞれ $\left.M_{m}, M_{a l}\right)$ を想定し、複合化後の位 置へ変形させるとすると、

$$
\begin{aligned}
& M_{m l}=E_{m l} I_{m}\left(1 / R_{c l}-1 / R_{m}\right) \\
& M_{a l}=E_{a l} I_{a}\left(1 / R_{c l}-1 / R_{a l}\right)
\end{aligned}
$$

となる。ここで、 $E_{m l} I_{m}, E_{a l} I_{a}$ は各々母材及び SMA の低温 時における曲げ剛性である。この両者が釣り合うことから、 複合化後の低温時の曲率半径

$$
\frac{1}{R_{c l}}=\frac{R_{a l} E_{m l} I_{m}+R_{m} E_{a l} I_{a}}{R_{m} R_{a l}\left(E_{m l} I_{m}+E_{a l} I_{a}\right)}
$$

が得られる。同様にして逆変態温度以上の高温時における 曲率半径も

$$
\frac{1}{R_{c h}}=\frac{R_{a h} E_{m h} I_{m}+R_{m} E_{a h} I_{a}}{R_{m} R_{a h}\left(E_{m h} I_{m}+E_{a h} I_{a}\right)}
$$

で求められ、可逆的な形状変化が定められる。ここで、 $E_{m h}$ $I_{m}, E_{a h} I_{a}$ は各々母材及び SMA の高温時における曲げ剛性 である。

次に、高温時において、複合体を Fig.1 の弧 OC'から低 温時形状の弧 OC まで形状変化させる動作を考える。先述 


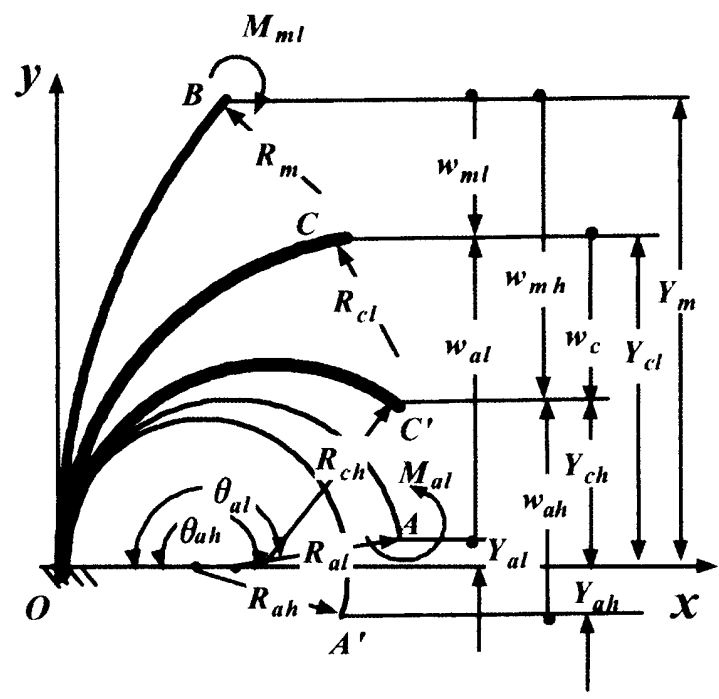

Fig. 1 Schemtical model of the shape memory composites

と同様に曲げモーメント $M_{c h}$ を想定すると、

$$
M_{c h}=(E I)^{*}\left(1 / R_{c h}-1 / R_{c l}\right)
$$

の関係がある。ここで $(E I)^{*}$ は複合体りングの高温時曲げ剛 性で、母材と SMA の曲げ剛性の和で与えられる。この $M_{c h}$ がなす仕事と $y$ 方向に引っ張った場合の荷重 $F^{\prime}{ }_{c h}$ がなす仕 事が等しいことから、 $F_{c h}^{\prime}$ を求めることができる。これは 低温状態において図 3 の点 C を拘束して、低温時の形状を 保持したまま、逆変態点温度以上に昇温させた時に同点に 発生する力を $F_{c h}$ と大きさが等しく逆方向の力である。よ って、下式のように発生荷重が定まる。

$$
F_{c h}=-F_{c h}{ }^{\prime}=-\frac{M_{c h}\left(\theta_{c h}-\theta_{c l}\right)}{Y_{c l}-Y_{c h}}
$$

\section{3. 実験方法}

SMA と複合化させる弾性体には CFRTPを用いた。一方 向 CF/PEEK プリプレグを 4 枚積層した。SMA には直径 $1.5 \mathrm{~mm}$ の TiNi ワイヤを用いた。SMA ワイヤは直径 $77.8 \mathrm{~mm}$ の円弧形状を記憶させ、CFRPは直径 $114 \mathrm{~mm}$ の円弧形状に 成形した。SMAワイヤを $1 \sim 4$ 本使用し、接着により CFRP と複合化し、 4 種類の試験体を作製した。示差走査熱量計 (DSC)により測定した SMA の相変態温度は $A_{s}=45^{\circ} \mathrm{C}$, $A_{f}=62^{\circ} \mathrm{C}, M_{s}=50^{\circ} \mathrm{C}, M_{f}=39^{\circ} \mathrm{C}$ で、実験を行う環境温度は低温 側を $20^{\circ} \mathrm{C}$ 、高温側を $80^{\circ} \mathrm{C}$ とした。

温度変化に伴う可逆的な形状変化については、複合体の 高温時および低温時における曲率半径と半弦長をそれぞれ 測定した。発生荷重に関しては、複合体の低温時形状のま ま拘束して温度上昇させ、Fig. 2 点 C に発生する荷重 $F_{c h}$ を 測定した。測定時の支持点は、低温時の状態で直径の位置 $\left(\theta_{c l}=90^{\circ}\right)$ とした。

\section{4. 実験結果}

可逆的形状変化に関しては、曲率半径の変化を測定した 結果を Fig. 2 に示す。使用した SMA ワイヤの本数にかかわ らず、高温時、低温時とも、モデルに基づいた計算結果と よく一致した結果が得られている。SMA ワイヤ4 本で高温 時での差が $4 \%$ となったのが最大誤差であった。

次に、発生荷重に関する実験結果とモデルから算出され
た結果の比較を Fig.3 に示す。低温時形状に拘束して昇温 した際に得られる加重 $F_{c h}$ についても、良好な一致をみて いる。

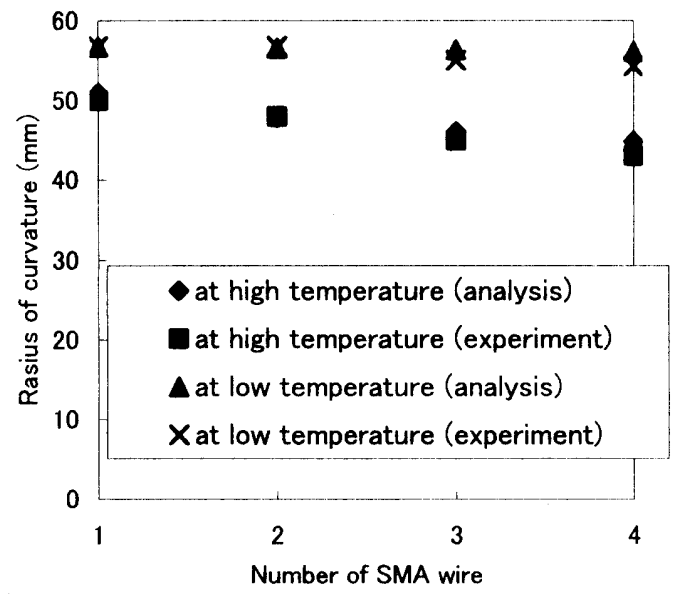

Fig. 2 Result of shape change (radius of curvature)

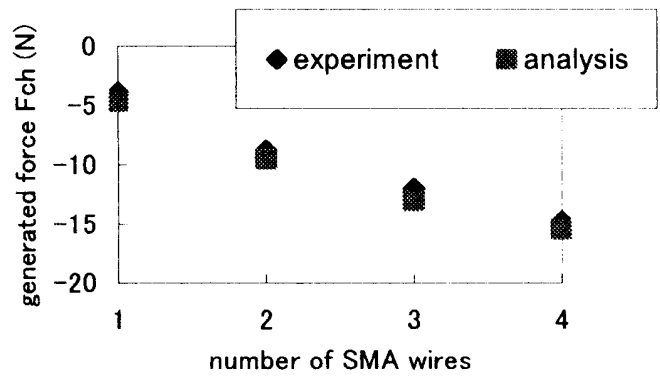

Fig. 3 Result of generated force

\section{5. 結 言}

本稿では、SMA ワイヤと弾性体とを複合化して、温度变 改によって可逆的に形状変化する材料について、リング形 状夕イプの場合に打いて、その形状変化ならびに発生荷重 について梁に基づきモデル化を行った。高温閉じ型の場合 において実験值との比較を行い、モデルの妥当性を検証し た。

\section{参考文嘀}

1) J.S.N.Paine and C.A.Rogers, Smart Struct. and Mater. 1994: Smart St ruct. and Intelligent Systems, SPIE Vol. 2190, 427 (1994)

2) H.Yoshida, Adv. Composite Mater., Vol.6, No.4, pp.341-352.

3) 吉田ら, FRP シンポジウム講演論文集, 日本材料学会, pp.169-172 (2001)

4) 永井ら, 強化プラスチックス, pp.513-522, (2002).

5) 吉田ら, JSME 材料力学部門講演会講演論文集, pp.325-326, (2002). 